\title{
EFFECT OF INSULIN HYPOGLYCEMIA AND GLUCOSE ADMINIS- TRATION ON THE LEVEL OF THE GLUTAMINE-LIKE SUBSTANCE IN BLOOD SERUM
}

\author{
By MEYER M. HARRIS with THE tEchnical ASSISTANCE OF ROSLYN T. ROTH \\ AND RUTH S. HARRIS \\ (From the Department of Internal Medicine, New York State Psychiatric Institute and \\ Hospital, New York City)
}

(Received for publication January 18, 1943)

That insulin hypoglycemic therapy in mental patients lowers the level of amino acids in the blood has been pointed out in a previous publication (1). Some investigators have reported that insulin and carbohydrate administrations decrease protein metabolism $(2,3,4)$. In the preceding paper, it was pointed out that glutamine might play a role in intermediary nitrogen metabolism and experiments were reported which demonstrated the presence of a glutamine-like substance $(G L S)^{1}$ in spinal fluid and blood serum and plasma, with many indications that this substance is most likely glutamine.

This paper deals with the effect of insulin hypoglycemia and of carbohydrate administration upon the level of this substance in the blood.

\section{METHODS}

The patients studied were all mentally ill persons who were receiving insulin hypoglycemic therapy. With the patients in a post-absorptive state, venous blood was drawn from the anterior cubital vein prior to insulin administration, and then at various intervals thereafter. The blood was collected under oil in some of the earlier studies; however, subsequent experiments indicated that this was an unnecessary precaution. ${ }^{2}$ The serum or plasma was separated by centrifuging after having been kept in the ice-box for about one-half hour following its collection. The protein was precipitated in a concentration of $10^{\circ}$ per cent trichloroacetic acid. The quantity of the glutamine-like substance in the filtrate was determined by Conway's micro-diffusion method (6), described in the previous paper. All determinations were carried out in duplicate or triplicate. It was pointed out in the preceding paper that the glutamine-like substance splits off completely its "amide" nitrogen as ammonia when heated in 10 per cent trichloroacetic acid for 1

1 (GLS) will be used as an abbreviation for glutaminelike substance in this paper.

2 The ammonia formed in shed blood, as reported by Conway (5), from adenosine, does not affect the determinations since we corrected for it in the blanks, prior to hydrolysis. hour and 15 minutes at $70^{\circ} \mathrm{C}$., and that any ammonia split off on more prolonged heating is due to some other substance, or substances, which hydrolyzes more slowly, as, for example, urea. Each determination, therefore, was carried out after acid hydrolysis at $70^{\circ} \mathrm{C}$., for 1 hour and 15 minutes and 2 hours and 30 minutes. This procedure acted as an additional check upon each determination. The very small difference between the ammonia liberated during the 2 intervals was used as a correction. As will be seen from the previous paper, this small difference may be due in whole or in large part to the decomposition of urea.

Concommitant blood sugar determinations, using the Folin-Wu method (7), were made on each blood specimen. (This represents fermentable and non-fermentable reducing substances in the blood.)

\section{OBSERVATIONS}

In Table $I$ are shown the effects of insulin administration on the level of the glutamine-like substance in the blood serum. In columns marked determinations (I) and (II) are given the ammonia liberated after 1 hour and 15 minutes, and 2 hours and 30 minutes of acid hydrolysis, respectively. The next column, marked corrected determination (III), represents the ammonia liberated by the glutamine-like substance and is obtained by subtracting the small difference (II minus I) from (I). The reason for this was given above in the section on methods. If one considers the ammonia in column III as derived from the "amide" nitrogen of glutamine, one can obtain the glutamine equivalent by multiplying by 10.4 the figures in column III. This is shown in column IV.

It will be seen from Table I that the initial post-absorptive level of the glutamine-like substance in the blood (expressed as glutamine equivalent per $100 \mathrm{ml}$. of serum) varies in different patients. Following insulin administration, the level gradually drops as the hypoglycemic state proceeds toward the period of hypoglycemic 
TABLE I

The effect of insulin hypoglycemia upon the level of the glutamine-like substance in the blood serum of mental patients

\begin{tabular}{|c|c|c|c|c|c|c|c|c|c|}
\hline \multirow{2}{*}{$\begin{array}{c}\text { Patient } \\
\text { and } \\
\text { case } \\
\text { number }\end{array}$} & \multirow{2}{*}{ Sex } & \multirow{2}{*}{$\begin{array}{l}\text { Dose of } \\
\text { insulin }\end{array}$} & \multirow{2}{*}{$\begin{array}{l}\text { Time with } \\
\text { relation to } \\
\text { insulin } \\
\text { injection }\end{array}$} & \multirow{2}{*}{$\begin{array}{l}\text { Blood } \\
\text { sugar } \\
\text { per } \\
100 \mathrm{ml} .\end{array}$} & \multicolumn{3}{|c|}{$\begin{array}{l}\text { Ammonia-N liberated per } 100 \mathrm{ml} . \\
\text { of serum } \dagger\end{array}$} & \multirow{2}{*}{$\begin{array}{l}\begin{array}{c}\text { Glutamine } \\
\text { equivalent } \\
\text { per } 100 \mathrm{ml} \\
\text { of serum }\end{array} \\
\text { (IV) }\end{array}$} & \multirow[b]{2}{*}{ Remarks } \\
\hline & & & & & $\begin{array}{c}\text { Determi- } \\
\text { nation } \\
\text { (I) }\end{array}$ & $\begin{array}{c}\text { Determi- } \\
\text { nation } \\
\text { (II) }\end{array}$ & $\begin{array}{c}\text { Corrected } \\
\text { determi- } \\
\text { nation } \\
\text { (III) }\end{array}$ & & \\
\hline M. S. & F. & $\begin{array}{l}\text { units } \\
175\end{array}$ & $\begin{array}{l}\text { Before } \\
2 \text { hours } \\
4 \frac{1}{2} \text { hours }\end{array}$ & $\begin{array}{r}m g m . \\
87 \\
70 \\
41\end{array}$ & $\begin{array}{l}m g m . \\
0.70 \\
0.72 \\
0.53\end{array}$ & $\begin{array}{l}m g m . \\
0.72 \\
0.76 \\
0.59\end{array}$ & $\begin{array}{l}m g m . \\
0.68 \\
0.68 \\
0.47\end{array}$ & $\begin{array}{r}m g m . \\
7.1 \\
7.1 \\
4.9\end{array}$ & No coma. \\
\hline F. F. & F. & 25 & $\begin{array}{l}\text { Before } \\
1 \frac{1}{2} \text { hours } \\
2 \frac{1}{2} \text { hours }\end{array}$ & $\begin{array}{l}98 \\
30 \\
37\end{array}$ & $\begin{array}{l}0.82 \\
0.81 \\
0.59\end{array}$ & $\begin{array}{l}0.86 \\
0.63\end{array}$ & $\begin{array}{l}0.78 \\
0.76 \\
0.55\end{array}$ & $\begin{array}{l}8.1 \ddagger \\
7.9 \\
5.7\end{array}$ & $\begin{array}{l}\text { Hypoglycemic symptoms. } \\
\text { Coma. }\end{array}$ \\
\hline $\begin{array}{c}\text { M. C. } \\
3\end{array}$ & M. & 115 & $\begin{array}{l}\text { Before } \\
2 \text { hours } \\
4 \text { hours } \\
1 \text { hour* }\end{array}$ & $\begin{array}{l}85 \\
37 \\
32 \\
91\end{array}$ & $\begin{array}{l}1.00 \\
0.70 \\
0.49 \\
0.47\end{array}$ & $\begin{array}{l}1.02 \\
0.78 \\
0.53\end{array}$ & $\begin{array}{l}0.98 \\
0.62 \\
0.43 \\
0.41\end{array}$ & $\begin{array}{l}10.2 \\
6.4 \\
4.5 \ddagger \\
4.3\end{array}$ & $\begin{array}{l}\text { Sweating, confused. } \\
100 \text { grams glucose orally, } \\
10 \text { grams glucose intra- } \\
\text { venously. }\end{array}$ \\
\hline M. D. & M. & 50 & $\begin{array}{l}\text { Before } \\
2 \text { hours } \\
4 \text { hours } \\
\frac{1}{2} \text { hour }\end{array}$ & $\begin{array}{r}102 \\
26 \\
27 \\
107\end{array}$ & $\begin{array}{l}0.93 \\
0.69 \\
0.61 \\
0.66\end{array}$ & $\begin{array}{l}0.99 \\
0.76 \\
0.66\end{array}$ & $\begin{array}{l}0.87 \\
0.62 \\
0.56 \\
0.60\end{array}$ & $\begin{array}{l}9.0 \\
6.4 \\
5.8 \\
6.2 \ddagger\end{array}$ & $\begin{array}{l}\text { Stupor. } \\
50 \text { grams glucose orally, } \\
10 \text { grams glucose intra- } \\
\text { venously. }\end{array}$ \\
\hline M. ${ }_{5}^{\prime} \mathrm{C}$. & F. & 50 & $\begin{array}{l}\text { Before } \\
2 \text { hours } \\
3 \text { hours } \\
1 \frac{1}{2} \text { hours* }\end{array}$ & $\begin{array}{r}91 \\
23 \\
28 \\
113\end{array}$ & $\begin{array}{l}0.96 \\
0.55 \\
0.49 \\
0.50\end{array}$ & $\begin{array}{l}1.02 \\
0.60 \\
0.56 \\
0.54\end{array}$ & $\begin{array}{l}0.90 \\
0.50 \\
0.42 \\
0.46\end{array}$ & $\begin{array}{l}9.4 \\
5.2 \\
4.4 \\
4.8\end{array}$ & $\begin{array}{l}\text { Confused. } \\
\text { Coma. } \\
100 \text { grams glucose orally, } \\
10 \text { grams glucose intra- } \\
\text { venously. }\end{array}$ \\
\hline S. G. & F. & 50 & $\begin{array}{l}\text { Before } \\
2 \text { hours } \\
4 \text { hours } \\
\frac{1}{2} \text { hour* }\end{array}$ & $\begin{array}{r}82 \\
24 \\
35 \\
143\end{array}$ & $\begin{array}{l}0.84 \\
0.57 \\
0.45 \\
0.60\end{array}$ & $\begin{array}{l}0.92 \\
0.63 \\
0.49 \\
0.63\end{array}$ & $\begin{array}{l}0.76 \\
0.51 \\
0.41 \\
0.57\end{array}$ & $\begin{array}{l}7.9 \\
5.3 \\
4.3 \\
5.9\end{array}$ & $\begin{array}{l}\text { Stupor. } \\
\text { Coma. } \\
125 \text { grams glucose orally. }\end{array}$ \\
\hline M. D. & F. & 100 & $\begin{array}{l}\text { Before } \\
2 \text { hours } \\
3 \frac{1}{2} \text { hours }\end{array}$ & & $\begin{array}{l}0.80 \\
0.55 \\
0.50\end{array}$ & $\begin{array}{l}0.81 \\
0.59 \\
0.52\end{array}$ & $\begin{array}{l}0.79 \\
0.51 \\
0.48\end{array}$ & $\begin{array}{l}8.2 \\
5.3 \\
5.0\end{array}$ & $\begin{array}{l}\text { Hypoglycemia, sweating. } \\
\text { Coma. }\end{array}$ \\
\hline
\end{tabular}

* This represents the time following the administration of glucose. The patients were all awake and relieved of their hypoglycemia. when these blood specimens were taken.

t Determination (I) represents the ammonia nitrogen liberated after acid hydrolysis for 1 hour and 15 minutes, and Determination (II) that obtained after hydrolysis for 2 hours 30 minutes. Corrected Determination (III) is obtained by subtracting the small correction $[$ (II) - (I) $]$ from (I).

Column IV is obtained by multiplying the values in column (III) by 10.4. The ammonia nitrogen being considered as the amide nitrogen of glutamine.

$\ddagger$ Since Determination II was not available for making the correction, the correction from the other figures in the series was used.

coma. It will be noted that case 1 , although receiving the largest dose of insulin (175 units), showed only a slight drop in the level of the blood sugar 2 hours after the injection of insulin, at which time there was no change in the level of the glutamine-like substance. After 41/2 hours, however, the level of both dropped appreciably. It would appear also from cases 1 and 2 that the level of the blood sugar drops sooner than that of the (GLS). In cases 3, 4, 5, and 6, in which the level of the (GLS) was determined from $1 / 2$ hour to $1 \frac{1}{2}$ hours after glucose was administered in order to bring the patient out of the hypoglycemic state, it will be observed that the level of (GLS) still remained appreciably depressed although there was a slight tendency for it to rise in all of these cases except case 3 .

As will be seen from Table II, the administra- 
TABLE II

The effect of glucose administration without insulin upon the level of the glutamine-like substance in the blood serum

\begin{tabular}{|c|c|c|c|c|c|c|c|}
\hline \multirow{2}{*}{$\begin{array}{l}\text { Patient and } \\
\text { case number }\end{array}$} & \multirow{2}{*}{ Sex } & \multirow{2}{*}{$\begin{array}{l}\text { Time in relation } \\
\text { to glucose } \\
\text { administration* }\end{array}$} & \multirow{2}{*}{$\begin{array}{l}\text { Blood sugar } \\
\text { per } 100 \mathrm{ml} .\end{array}$} & \multicolumn{3}{|c|}{ Ammonia- $\mathrm{N}$ liberated per $100 \mathrm{ml}$. of serum $\dagger$} & \multirow{2}{*}{$\begin{array}{c}\text { Glutamine equivalent } \\
\text { per } 100 \mathrm{ml} \text {. of serum } \\
\text { (IV) }\end{array}$} \\
\hline & & & & $\begin{array}{l}\text { Determination } \\
\text { (I) }\end{array}$ & $\begin{array}{l}\text { Determination } \\
\text { (II) }\end{array}$ & $\begin{array}{c}\text { Corrected } \\
\text { determination } \\
\text { (III) }\end{array}$ & \\
\hline E. K. & M. & $\begin{array}{l}\text { Before } \\
1 \text { hour } \\
2 \text { hours } \\
3 \frac{1}{2} \text { hours }\end{array}$ & $\begin{array}{r}\text { mgm. } \\
104 \\
154 \\
89 \\
62\end{array}$ & $\begin{array}{c}\text { mgm. } \\
1.03 \\
0.88 \\
0.83 \\
0.82\end{array}$ & $\begin{array}{c}\text { mgm. } \\
1.08 \\
0.91 \\
0.87 \\
0.90\end{array}$ & $\begin{array}{c}\text { mgm. } \\
0.98 \\
0.85 \\
0.79 \\
0.74\end{array}$ & $\begin{array}{r}\text { mgm. } \\
10.2 \\
8.9 \\
8.2 \\
7.7\end{array}$ \\
\hline R. S. & M. & $\begin{array}{l}\text { Before } \\
1 \text { hour } \\
2 \text { hours } \\
3 \frac{1}{2} \text { hours }\end{array}$ & $\begin{array}{r}92 \\
173 \\
121 \\
88\end{array}$ & $\begin{array}{l}0.97 \\
0.83 \\
0.69 \\
0.67\end{array}$ & $\begin{array}{l}1.01 \\
0.89 \\
0.77 \\
0.73\end{array}$ & $\begin{array}{l}0.93 \\
0.76 \\
0.61 \\
0.61\end{array}$ & $\begin{array}{l}9.7 \\
7.9 \\
6.3 \\
6.3\end{array}$ \\
\hline
\end{tabular}

- 75 grams of glucose given orally to each patient in post absorptive state.

† See legend for Table (I).

tion of glucose without insulin also tends to depress the level of (GLS) in the blood. However, this is not as marked as that resulting from insulin administration. Apparently, where the level of the (GLS) has been appreciably depressed during insulin hypoglycemia, the administration of glucose does not produce any additional depression in the blood level of this substance. These effects are similar to those reported in a previous paper (1) regarding the level of the amino acids in the blood under similar conditions.

Since the cases receiving insulin did not receive any food until noon, it was necessary to control the effect of this prolonged post-absorptive period. From Table III it will be seen that a comparable

TABLE III

Effect of the post-absorptive state on the level of the glutaminelike substance in the blood serum

\begin{tabular}{|c|c|c|c|c|c|c|}
\hline \multirow{2}{*}{$\begin{array}{l}\text { Patient } \\
\text { and case } \\
\text { number }\end{array}$} & \multirow{2}{*}{ Sex } & \multirow{2}{*}{$\begin{array}{l}\text { Time } \\
\text { post- } \\
\text { absorp- } \\
\text { tive }\end{array}$} & \multicolumn{3}{|c|}{$\begin{array}{l}\text { Ammonia - N liberated per } \\
100 \mathrm{ml} \text {. of serumt }\end{array}$} & \multirow{2}{*}{$\begin{array}{c}\text { Glutamine } \\
\text { equivalent } \\
\text { per } 100 \mathrm{ml} \\
\text { of serum } \\
\text { (IV) }\end{array}$} \\
\hline & & & $\begin{array}{c}\text { Determi- } \\
\text { nation } \\
\text { (I) }\end{array}$ & $\begin{array}{c}\text { Determi- } \\
\text { nation } \\
\text { (II) }\end{array}$ & $\begin{array}{c}\text { Corrected } \\
\text { determi- } \\
\text { nation } \\
\text { (III) }\end{array}$ & \\
\hline \multirow{2}{*}{ E. $\mathrm{K}$. } & & hours & mgm. & mgm. & $m g m$. & mgm. \\
\hline & M. & $\begin{array}{l}16 \\
19\end{array}$ & $\begin{array}{l}0.99 \\
1.05\end{array}$ & $\begin{array}{l}1.08 \\
1.12\end{array}$ & $\begin{array}{l}0.90 \\
0.98\end{array}$ & $\begin{array}{r}9.4 \\
10.2\end{array}$ \\
\hline R. S. & M. & $\begin{array}{l}16 \\
19\end{array}$ & $\begin{array}{l}0.97 \\
0.95\end{array}$ & $\begin{array}{l}1.01 \\
1.03\end{array}$ & $\begin{array}{l}0.93 \\
0.87\end{array}$ & $\begin{array}{l}9.7 \\
9.1\end{array}$ \\
\hline
\end{tabular}

* These patients are the same as those used for tests in Table II. Although these control observations were made on different days from those for Table II, note the similarity of the figures with those before glucose administration in Table II.

† See legend for Table I. post-absorptive period without insulin had practically no effect upon the level of the (GLS) in the blood, thus showing that the period of fasting is not a factor in the phenomena observed.

\section{DISCUSSION}

These studies clearly indicate that carbohydrate administration and insulin hypoglycemia depress the level of the (GLS) in the blood, the effect of the latter being very much more marked. The effect of insulin on the blood sugar level is more rapid than that on the level of the (GLS). It will also be noted that the (GLS) in the blood reaches a minimum level of about $4 \mathrm{mgm}$. of glutamine equivalent per $100 \mathrm{ml}$. of serum. When glucose in large amounts is administered during the insulin hypoglycemia, no further depression in the level of (GLS) occurs (cases 4, 5, 6, Table I) ; in fact, there is a tendency for the level to rise.

Some in vitro studies seem to indicate that insulin may have a direct specific effect on protein metabolism. Bach and Holmes (8) found that urea formation and carbohydrate synthesis from some amino acids, by normal rat liver slices in vitro, is depressed by the addition of insulin. They concluded on the basis of their studies that one of the actions of insulin is to suppress glyconeogenesis by inhibiting the oxidative deamination of glycogenic amino acids. Stadie, Lukens and Zapp (9), in similar in vitro experiments, also demonstrated the inhibitory action of insulin on oxidative deamination. However, they found that this action was limited to the unnatural d-isomers of the amino acids investigated. 
It may be of interest to attempt an interpretation of our findings on the basis of these in vitro studies. It would appear that several mechanisms may be involved. The administration of carbohydrate, perhaps aided by one of the actions of insulin, depresses protein metabolism, and thereby decreases the supply of amino acids in the metabolic mixture which is the source of the amino groups which are necessary for the synthesis of the (GLS). The specific direct action of insulin on protein metabolism depresses the oxidative deamination of the unnatural $d$-isomers of amino acids occurring in the metabolic mixture, thereby decreasing the supply of deaminated amino groups for the formation of (GLS). This action of insulin produces the most marked effect since it would interfere with the formation of the (GLS) even if the supply of amino acids were adequate. This phase of the problem of the effect of the administration of amino acids is now under investigation. We have found thus far that certain amino acids raise the level of (GLS) in the blood. This work will be reported later.

Krebs $(10,11)$ has shown that the enzyme glutaminase will not synthesize glutamine in vitro if a source of energy such as glucose is not present in the substrate. Since in the hypoglycemic state the supply of glucose via the blood stream is inadequate, the synthesis of glutamine by various organs like the brain, kidneys, and retina may be depressed. This could account for the slight rise in the level of the (GLS) following the alleviation of the hypoglycemic state by the administration of glucose (cases 4, 5, 6, Table I). However, as will be seen from the table, the main specific inhibiting effect. of insulin continues, even though the level of the blood sugar is brought back to normal.

Since, according to Stadie and his co-workers (9), the oxidative deamination of the natural isomers of the amino acids is not inhibited by insulin, this could be a source of amino groups for the formation of some of the (GLS) during the hypoglycemic period.

The coma occurring during the prolonged hypoglycemia does not appear to be due to inhibition of the formation of (GLS), since the patients can be brought out of coma by the administration of glucose while the level of (GLS) in the blood remains depressed. This, however, does not preclude the possibility that the effect on protein me- tabolism by the specific action of insulin and the hypoglycemic state may play some role in the insulin shock therapy of mental patients.

Since other hormones $(4,12$ to 15$)$, and also some of the vitamins $(16,17)$, apparently play a role in protein metabolism, their relation to the formation of the glutamine-like substance will be the object of subsequent investigations.

\section{SUMMARY}

1. It has been shown that insulin and also carbohydrate administration lower the level of a glutamine-like substance (GLS) present in the blood.

2. This effect of insulin is more marked than that due to carbohydrate administration.

3. The effect of insulin on the level of (GLS) continues after the insulin hypoglycemia is alleviated by glucose.

4. Some possible mechanisms which may explain the observations are discussed and plans for further investigations are indicated.

\section{BIBLIOGRAPHY}

1. Harris, M. M., Blalock, J. R., and Horwitz, W. A., Metabolic studies during insulin hypoglycemia therppy of the psychoses. Arch. Neurol. and Psychiat., 1938, 40, 116.

2. Long, C. N. H., Katzin, B., and Fry, E. G., Adrenal cortex and carbohydrate metabolism. Endocrinology, 1940, 26, 309.

3. Lusk, G., The Elements of Science of Nutrition. W. B. Saunders, Philadelphia, 1928. The influence of carbohydrate on protein metabolism and protein retention, p. 352.

4. Long, C. N. H., Metabolic functions of the endocrine glands. Ann. Rev. Physiol., 1942, 4, 465.

5. Conway, E. J., Apparatus for micro-determination of certain volatile substances. The blood ammonia with observations on normal human blood. Biochem. J. 1935, 29, 2755.

Conway, E. J., and Cooke, R., Blood ammonia. Biochem. J., 1939, 33, 457.

6. Conway, E. J., Micro-Diffusion Analysis and Volumetric Error. Crosby, Lockwood and Son, Ltd., London, 1939.

7. Folin, O., and Wu, H., Simplified and improved method for determination of sugar. J. Biol. Chem., 1920, 41, 367.

8. Bach, S. J., and Holmes, E. G., Effect of insulin on carbohydrate formation in the liver. Biochem. J., 1937, 31, 89.

9. Stadie, W. C., Lukens, F. D. W., and Zapp, J. A., Jr., The effect of insulin upon urea formation, car- 
bohydrate synthesis, and respiration of liver of normal and diabetic animals. J. Biol. Chem., 1940, 132, 393.

10. Krebs, H. A., Metabolism of amino acids. The synthesis of glutamine from glutamic acid and ammonia, and the enzymatic hydrolysis of glutamine in animal tissues. Biochem. J., 1935, 29, 1951.

11. Örström, A., Örström, M., Krebs, H. A., and Eggleston, L. V., The synthesis of glutamine in pigeon liver. Biochem. J., 1939, 33, 995.

12. Marx, W., Magy, D. B., Simpson, M. E., and Evans, H. M., Effect of purified pituitary preparations on urine nitrogen in the rat. Am. J. Physiol., 1942, 137, 544.

13. Jones, R., McCullagh, E. P., McCullagh, D. R., and Buckaloo, G. W., Methyl testosterone. Observa- tions on the hypermetabolism induced by methyltestosterone. J. Clin. Endocrinol., 1941, 1, 656.

14. Knowlton, K., et al., Comparative study of metabolic effects of estradiol benzoate and testosterone propionate in man, J. Clin. Endocrinol., 1942, 2, 671.

15. Kenyon, A. T., et al., Comparison of metabolic effects of testosterone propionate with those of chorionic gonadotropin. J. Clin. Endocrinol., 1942, 2, 685.

16. Sure, B., and Ford, Z. W., Jr., Influence of thiamine, riboflavin, pyridoxine, and pantothenic acid deficiencies on nitrogen metabolism. J. Nutrition, 1942, 24, 405.

17. Griffith, W. H., and Mulford, D. J., Choline metabolism. VII. Some dietary factors affecting incidence and severity of hemorrhagic degeneration in young rats. J. Nutrition, 1941, 21, 633. 